\title{
Evaluation of Long Term Performance for Initial Public Offerings using Market Adjusted Cumulative Abnormal Returns (MACAR): A Case Study of Islamic Finance in Malaysia
}

\author{
Nashirah Abu Bakar ${ }^{1}$ Sofian Rosbi $^{2}$ and Kiyotaka Uzaki ${ }^{3}$ \\ ${ }^{1}$ Islamic Business School, College of Business, University Utara Malaysia, Kedah, Malaysia \\ ${ }^{2}$ School of Mechatronic Engineering, University Malaysia Perlis, Malaysia \\ ${ }^{3}$ Faculty of Economics, Oita University, Japan
}

\begin{abstract}
The main objective of this paper is to evaluate the long term performance of initial public offerings for sharia compliant companies listed on the Malaysia Stock Exchange. The number of selected companies is 17 that issued initial public offerings (IPO) in the year of 2014 and 2015. Data for analysis in this study are collected from Thomson Reuters Datastream. The daily stock price is collected and then averaged to attained monthly share price. Next, this study using market adjusted cumulative abnormal returns (MACAR) to evaluate the performance of initial public offerings. In the same time, this study implemented the Shapiro-Wilk normality test to check the normality of data distribution. The result shows the MACAR value is -46.0024\% for 17 sharia-compliant companies. The negative value indicates the companies performed less than the benchmarked market namely Kuala Lumpur Stock Exchange (KLSE). Therefore, the findings show the market performed better than companies that issued IPO. The importance of this finding is it will help investors to make a better decision in developing their investment portfolio in gaining better profit and reducing the loss. In addition, the findings also will help the financial analyst to understand the dynamic behavior of the financial environment in Malaysia Stock Exchange.
\end{abstract}

Key Words: Islamic Finance, Initial Public Offerings, Long Term Performance, Cumulative Abnormal Returns.

\section{INTRODUCTION}

Initial public offerings (IPO) have been studied extensively in the developed markets. In Malaysian market, IPO are found to underperform the market value. Study by Ahmad-Zaluki and Kect, (2012) found IPO companies are underperforms the market value during the period of study 2002 to 2005 in Malaysian market. While Zarafat and Vejzagic (2014) investigate the long run (six-month, one-year, two-year, and three-year) returns of IPO listed on the Malaysian Stock Exchange during the period of 2004 till 2007. They found that the long term performance of IPO companies are underperformance with average market adjusted return for the six-month, one-year, two-year, and three-year after listing are $-5.2 \%,-10.8 \%,-21.4 \%$, and $-32.8 \%$.

Besides that, several study regarding long run performance of IPO found that IPO are outperformed the market value. Corhay, et al., (2002) concluded that IPO tend to outperform the market with a positive cumulative adjusted market return (CAR) of $41.7 \%$ over three years from the listing day during the period of 1992-1996.

Recent study show the long term performance of IPO companies in Malaysian market is below than market value (Ahmad-Zaluki and Kect, 2012; Zarafat and Vejzagic, 2014). Although a number of research internationally and locally have investigated the aftermarket performance of initial public offerings, this study makes a new contribution to the expansion of the IPO literature by providing a comprehensive sample of sharia compliant companies listed on the Malaysian Stock Exchange. This study try to fulfill the gap by examine the long term performance of IPO for sharia compliant companies from 2014 till 2015 using a market adjusted cumulative abnormal return method (MACAR). 
International Journal of Advances in Scientific Research and Engineering (ijasre), Vol 5 (1), January-2019

\section{LITERATURE REVIEW}

A number of theories have been put forward to explain the phenomenon of short term and long term performance of IPO (Chahine and Tohme, 2009; Islam, et al., 2010; Chi and Padgett, 2005; Heerden and Alagidede, 2012; Samarakoon, 2010; Ekkayokkaya and pengniti, 2012; Darmadi and Gunawan, 2012; Agathee, et al., 2012 Borges, 2007; Ahmad-Zaluki and Kect, 2012; Goergen, et al., 2007; Chi and Padgett, 2005; Drobetz, et al., 2005; Chan, et al., 2004; Ritter, 1991; Carter et al., 1998; Lee, et al., 1996; Abu Bakar and Rosbi, 2016). Previous study has shown that IPO companies experience stock price underperformed. Giudici and Roosenboom (2004) found that the average company that went public on the Europe markets has been a very poor long term investment.

Liang (2008) study the long term performance of IPO listed on the China's Shanghai Stock Exchange found that the average market-adjusted cumulative return and buy-and-hold return over the three years after listing are $-32.02 \%$ and $-20.88 \%$ respectively. Chan, et al. (2003) has also reported the same results in China. They found IPOs in China also slightly underperformed. Cai and Wei (1997) measured IPOs performance in Japan and found that IPOs underperformed their benchmarks. The previous study shows that a significant negative long term performance indicates the companies are inconsistent performance with market efficiency.

Study by Kooli and Suret (2004) investigated long-term performance in Canada found that IPO are underperformed. Levis (1993) found the long-term performance of IPO in the United Kingdom are underperformed using the CAR and BHAR methods. Goergen et al., (2007) also investigates the long term performance of IPO in United Kingdom found that small company behave differently from large companies and suffer from worse long term performance than large companies. While, Ritter (1991) examined long-term performance of IPOs in the United States and found the significantly underperformed their benchmarks using CAR and BHAR methods. Carter et al. (1998) also found IPO stocks were underperformed relative to the market over a three-year holding period and less severe for IPO handled by underwriters with more prestige.

While, Lee, et al. (1996) reported that Australian IPOs significantly underperformed market movements in the three-year period after list. Drobetz et al. (2005) indicated that long-term performance of Swiss IPO and found that IPO underperformed their benchmarks. How, et al. (2011) found robust results that companies, which initiated a dividend, perform significantly better up to five years after the initiation date in Australia. Bessler and Thies (2007) found that the subsequent financing activity on the equity market is the most important factor in determining the future performance of IPOs in Germany.

\section{RESEARCH METHODOLOGY}

In answering the research objective in this study, a few steps of calculation need to be performed to validate the findings. This study performed return calculation for stock price, abnormal return analysis and normality diagnostics checking.

\subsection{Data selection and market adjusted cumulative abnormal returns (MACAR) calculation}

This study selected 17 sharia compliant companies that issued IPO for year of 2014 and 2015. These companies are listed in main market of Malaysia Stock Exchange. This study collected daily stock price from Thomson Reuters Datastream. The selected periods is starting from January 2016 until December 2018 involving 36 months observations. The average monthly share price for one particular month $t$ is calculated using Equation (1).

$M P_{t}=\frac{\sum_{i=1}^{n} D P_{i}}{n}$

In Equation (1), these variables are defined as follows:

$M P_{t}$ : Average monthly share price for particular month $t$,

$D P_{i}$ : Daily share price for particular trading day $i$, and

$n$ : Number of trading days in particular month $t$.

Then, this study calculated the monthly return for particular month $t$ using Equation (2).

$R_{i, t}=\left(\frac{M P_{t}-M P_{t-1}}{M P_{t-1}}\right) \times 100 \%$ 
In Equation (2), the variables are defined as below:

$R_{i, t}$ : Return for company $i$ in month $t$,

$M P_{t}$ : Average monthly share price for particular month $t$, and

$M P_{t-1}$ : Average monthly share price for particular month $t-1$.

Next, this study calculated for return with benchmarking to the market namely Kuala Lumpur Stock Exchange. Equation (3) shows the equation for market adjusted return.

$A R_{i, t}=R_{i, t}-R_{m, t}$

In Equation (3), the variables are described as follows:

$A R_{i, t}$ : Abnormal return for company $i$ in month $t$,

$R_{i, t}:$ Return for company $i$ in month $t$, and

$R_{m, t}$ : Return for benchmark market (Kuala Lumpur Stock Exchange) in month $t$.

Then, this study derived average abnormal returns for each month in long term periods of 36 months as shown in Equation (4).

Average $A R_{i, t}=\frac{\sum_{i=1}^{N} A R_{i, t}}{N}$

In Equation (4), the variables are described as below:

Average $A R_{i, t}$ : Average abnormal returns for month $i$,

$A R_{i, t}:$ Abnormal return for company $i$ in month $t$, and

$N$ : Number of companies in sample.

Next, this study calculated long term performance of IPO using market adjusted cumulative abnormal returns (MACAR) as described in Equation (5).

$\mathrm{MACAR}=\sum_{t=1}^{36}\left(\frac{\sum_{i=1}^{N} A R_{i, t}}{N}\right)$

\subsection{Statistical test for normality of data distribution}

Shapiro-Wilk normality test is performed to evaluate the normal distribution of data. The normal distribution, also known as the Gaussian distribution, is a probability distribution that is symmetric about the mean, showing that data near the mean are more frequent in occurrence than data far from the mean.

A normal distribution for variable $x$ with mean $\mu$ and variance $\sigma^{2}$ is a statistic distribution with probability density function as stated in Equation (6).

$P(x)=\frac{1}{\sigma \sqrt{2 \pi}} e^{-\frac{(x-\mu)^{2}}{2 \sigma^{2}}}$

Domain for $x$ variable is considered in the range of $x \in(-\infty,+\infty)$. 
The statistical test performed in this study is using Shapiro-Wilk normality test. The Shapiro-Wilk test tests the null hypothesis that a sample $\left(x_{1}, x_{2}, x_{3}, \ldots, x_{n}\right)$ came from a normally distributed population. The test statistic is represented by Equation (7).

$W=\frac{\left(\sum_{i=1}^{n} a_{i} x_{(i)}\right)^{2}}{\sum_{i=1}^{n}\left(x_{i}-\bar{x}\right)^{2}}$

In Equation (7), the parameters are described as follows:

$x_{(i)}$ : Order statistics for $x$ variable. The variable $x_{(1)}$ is the smallest order statistics.

$\bar{x}$ : Sample mean of variable $x$. The equation of sample mean is represented by $\bar{x}=\frac{\left(x_{1}, x_{2}, x_{3}, \ldots, x_{n}\right)}{n}$.

$a_{i}:$ The coefficient for $W$ statistics.

$\left(a_{1}, a_{2}, a_{3}, \ldots, a_{n}\right)=\frac{m^{\mathrm{T}} V^{-1}}{\left(m^{\mathrm{T}} V^{-1} V^{-1} m\right)^{\frac{1}{2}}}$

The parameters for Equation (4) are described as follows:

$m$ : A vector made of the expected values of the order statistics of independent and identically distributed random variables sampled from the standard normal distribution.

$V:$ The covariance matrix of order statistics.

If the significant value ( $\mathrm{p}$-value) of Shapiro-Wilk test is larger than 0.05 , the data distribution follows normal distribution. However, if the significant value ( $\mathrm{p}$-value) is less than 0.05 , the data distribution deviates from normal distribution.

\section{RESULT AND DISCUSSION}

The objective of this study is to validate the long term performance of IPO for companies listed on the Malaysia Stock Exchange. The selected companies are 17 sharia compliant companies that issued initial public offerings in year of 2014 and 2015 . Table 1 shows the list of 17 selected companies and year of initial public offering issued.

Table 1: List of sharia compliant companies issued IPO in year of 2014 and 2015

\begin{tabular}{|c|l|c|}
\hline No. & \multicolumn{1}{|c|}{ Companies } & Year of IPO issued \\
\hline $\mathbf{1}$ & BIOALPHA HOLDINGS BERHAD & 2015 \\
\hline $\mathbf{2}$ & MALAKOFF CORPORATION BERHAD & 2015 \\
\hline $\mathbf{3}$ & DOLPHIN INTERNATIONAL BERHAD & 2015 \\
\hline $\mathbf{4}$ & XIN HWA HOLDINGS BERHAD & 2015 \\
\hline $\mathbf{5}$ & IKHMAS JAYA GROUP BERHAD & 2015 \\
\hline $\mathbf{6}$ & SUNWAY CONSTRUCTION GROUP BERHAD & 2015 \\
\hline $\mathbf{7}$ & AEMULUS HOLDINGS BERHAD & 2015 \\
\hline $\mathbf{8}$ & AL-SALAM REAL ESTATE INVESTMENT TRUST & 2015 \\
\hline $\mathbf{9}$ & IOI PROPERTIES GROUP BERHAD & 2014 \\
\hline $\mathbf{1 0}$ & SCH GROUP BERHAD & 2014 \\
\hline $\mathbf{1 1}$ & ICON OFFSHORE BERHAD & 2014 \\
\hline
\end{tabular}


International Journal of Advances in Scientific Research and Engineering (ijasre), Vol 5 (1), January-2019

\begin{tabular}{|c|l|l|}
\hline $\mathbf{1 2}$ & BOUSTEAD PLANTATIONS BHD & 2014 \\
\hline $\mathbf{1 3}$ & ECONPILE HOLDINGS BHD & 2014 \\
\hline $\mathbf{1 4}$ & SASBADI HOLDINGS BHD & 2014 \\
\hline $\mathbf{1 5}$ & CARIMIN PETROLEUM BERHAD & 2014 \\
\hline $\mathbf{1 6}$ & E.A.TECHNIQUE (M) BERHAD & 2014 \\
\hline $\mathbf{1 7}$ & KRONOLOGI ASIA BERHAD & 2014 \\
\hline
\end{tabular}

Next, this study performed calculation of average cumulative abnormal return to evaluate the performance of IPO among 17 sharia compliant companies. Figure 1 shows average abnormal returns for long term performance of 36 months. The first observation is in January 2016 with average abnormal return is $0.6827 \%$. The value of average abnormal return in last observation of $36^{\text {th }}$ month (December 2018) is $-10.9647 \%$. Meanwhile, the value of market adjusted cumulative abnormal returns (MACAR) is $-46.0024 \%$.

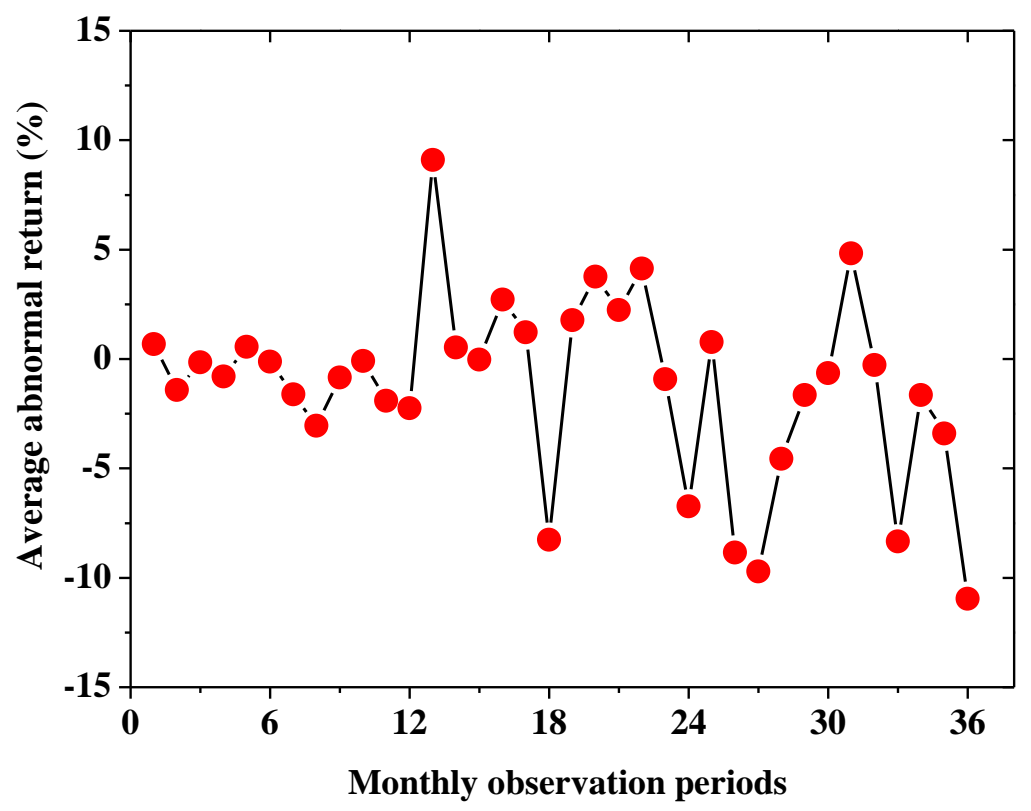

Figure 1: Average abnormal returns for long term performance of 36 months

Then, this study performed normality statistical test using graphical and statistical method. Figure 2 shows histogram for average abnormal returns for sharia compliant companies that issued IPO in year of 2014 and 2015 . The red line in the histogram indicates the reference line of normal data distribution. Figure 1 indicates the data distribution follow normal distribution.

In addition, this study performed normal Q-Q (quantile - quantile) plot analysis. Figure 2 shows the normal Q-Q plot for average abnormal returns of sharia compliant companies that issued IPO in year of 2014 and 2015. The red line is the reference line for normal distribution. Figure 2 shows all data are distributed near to normal distribution line. Therefore, data distributions of average abnormal returns follow normal distribution. 


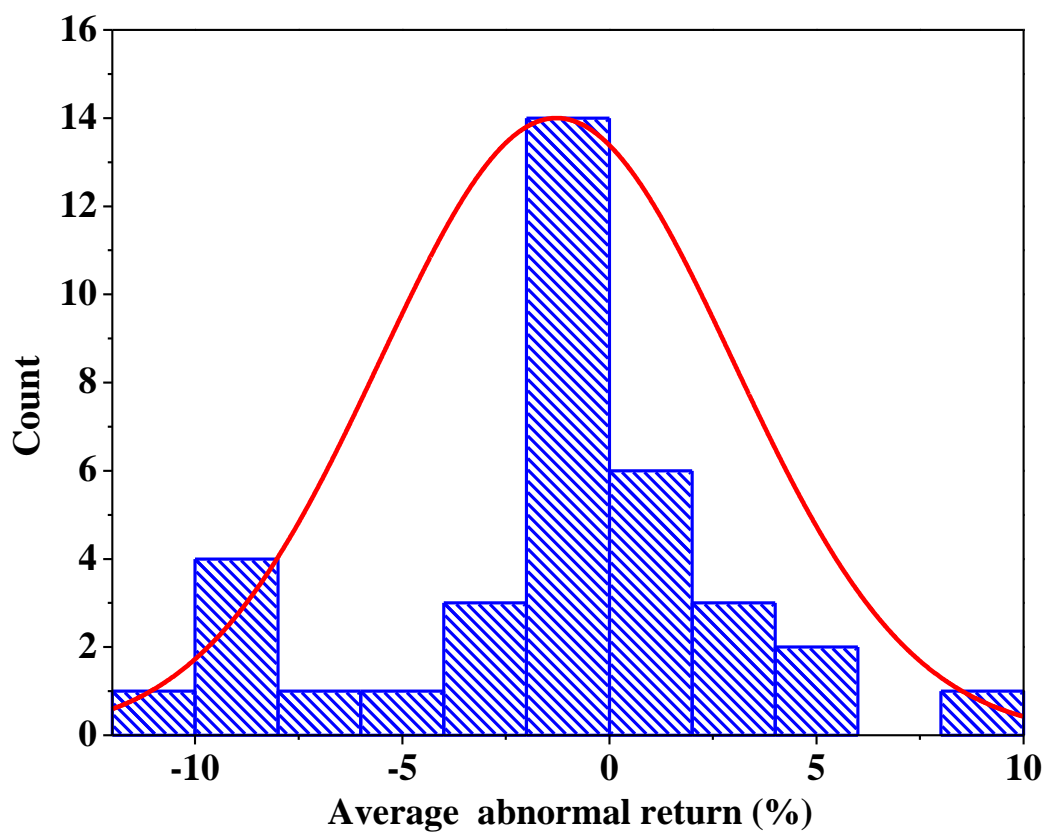

Figure 2: Histogram for average abnormal returns

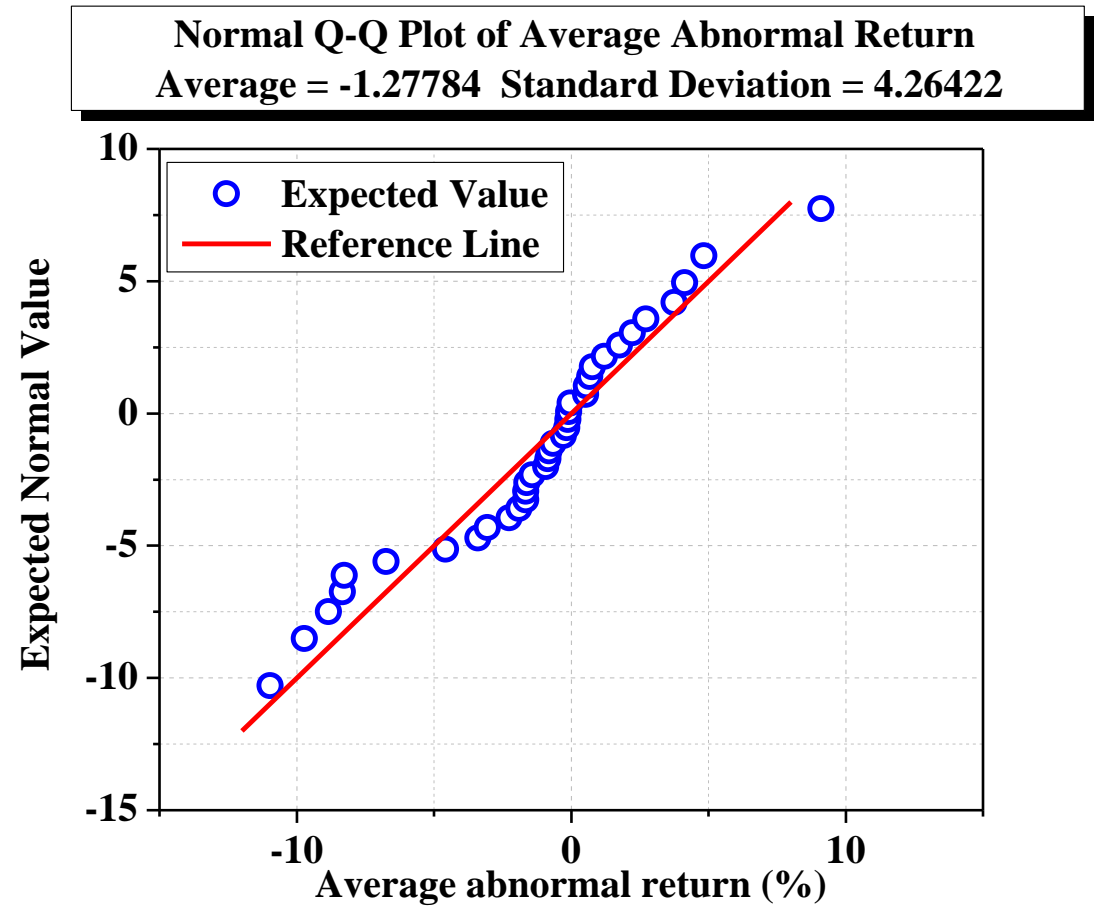

Figure 3: Normal Q-Q plot for average abnormal returns

Next, this study performed statistical test to evaluate the normality of data distribution in validating the findings in graphical method. Table 2 shows Shapiro-Wilk normality test for average abnormal return of sharia compliant companies that issued IPO in year of 2014 and 2015.Table 2 shows the significant value is 0.060 . This value is larger than 0.05 . Therefore, this study failed to reject null hypothesis of Shapiro-Wilk normality test. As a conclusion, the data distributions of average abnormal return follow normal distribution according to Shapiro-Wilk normality test.

Table 2: Shapiro-Wilk normality test for average abnormal return

\begin{tabular}{|c|c|c|}
\hline \multicolumn{3}{|c|}{ Shapiro-Wilk normality test } \\
\hline Statistics & Degree of freedom & Significant value (p-value) \\
\hline 0.942 & 36 & 0.060 \\
\hline
\end{tabular}




\section{CONCLUSION}

The main objective of this paper is to evaluate the long term performance for 17 sharia compliant companies that issued IPO in year of 2014 and 2015. The main finding of this study is the value of market adjusted cumulative abnormal returns (MACAR) is $46.0024 \%$. Negative value MACAR indicates companies performed less than the market (Kuala Lumpur Stock Exchange). This finding from this study will help investors to understand the financial environment in Malaysia. In addition, it will help investors to make proper evaluation in developing investment portfolio between different financial assets.

\section{REFERENCES}

[1]. S. Chahine, and N.S. Tohme, "Is CEO Duality Always Negative? A Exploration of CEO Duality and Ownership Structure in the Arab IPO Context”, Corporate Governance: An International Review, 2009, 17(2):123-141.

[2]. N.A. Ahmad-Zaluki, K. Campbell, and A. Goodacre, "The Long Run Share Price Performance of Malaysian Initial Public Offerings (IPOs)", Journal of Business and Accounting, 2007, 34(1):78-110.

[3]. H. Zarafat and M. Vejzagic, "The Long-Term Performance of Initial Public Offerings: Evidence from Bursa Malaysia”, Journal of Applied Economics and Business Research, 2014, 4(1):42-51.

[4]. A. Corhay, S. Teo and A.T. Rad, "The long-run performance of Malaysian initial public offerings (IPO): value and growth effects", Managerial Finance, 2002, 28(2):52-65.

[5]. S. Chahine, and N.S. Tohme, "Is CEO Duality Always Negative? A Exploration of CEO Duality and Ownership Structure in the Arab IPO Context”, Corporate Governance: An International Review, 2009, 17(2):123-141.

[6]. A. Islam, R. Ali, and Z. Ahmad, "An Empirical Investigation of the Underpricing of Initial Public Offerings in the Chittagong Stock Exchange”, International Journal of Economics and Finance, 2010, 2(4):36-46.

[7]. J. Chi, J. and C. Padgett, "Short-run underpricing and its characteristics in Chinese initial public offering (IPO) markets", Research in International Business and Finance, 2005, 19(1):71-93.

[8]. G.V. Heerden, and P. Alagidede, "Short run underpricing of initial public offerings (IPOs) in the Johannesburg Stock Exchange (JSE)", Review of Development Finance, 2012, 2:130-138.

[9]. L.P. Samarakon, "The Short-Run Underpricing of Initial Public Offerings in the Sri Lakan Stock Market”, Journal of Multinational Financial Management, 2010, 20:197-213.

[10].M. Ekkayokkaya and T. Pengniti, "Governance reform and IPO underpricing”, Journal of Corporate Finance, 2012, 18(2):238-253.

[11].S. Darmadi, and R. Gunawan, "Underpricing, board structure, and ownership: An empirical examination of Indonesian IPO firms", Managerial Finance, 2013, 39(2):181-200.

[12].C. Zhang (Xinde), and T.H.D. King, "The Decision to Cross-List: The Case of Chinese IPOs and ADRs", SSRN Electronic Journal, 2008.

[13].U. S. Agathee, R.V. Sannassee, and C. Brooks, "The underpricing of IPOs on the Stock Exchange of Mauritius", Research in International Business and Finance, 2012, 26(2):281-303.

[14].M.R. Borges, "Underpricing of Initial Public Offerings: The Case of Portugal", International Advances in Economic Research, 2006, 13(1):65-80.

[15].M. Goergen, A. Khurshed and R. Mudambi, “The long-run performance of UK IPOs: can it be predicted?" Managerial Finance, 2007, 33(6):401-419.

[16].J. Chi, and C. Padgett, "Short-run underpricing and its characteristics in Chinese initial public offering (IPO) markets", Research in International Business and Finance, 2005, 19(1):71-93.

[17].W. Drobetz, M. Kammermann, and U. Walchli, "Performance of Initial Public Offerings: The Evidence for Switzerland”, Schmalenbach Business Review, 2005, 57 (3):253-275.

[18].K. Chan, J. Wang, and K.C.J. Wei "Underpricing and long term performance of IPOs in China", Journal of Corporate Finance, 2004, 10(3):409-430.

[19]. J.R. Ritter, “The Long Run Performance of Initial Public offerings”, Journal of Finance, 1991, 46(1):3-27.

[20].R.B. Carter, F.H. Dark and A.K. Singh, "Underwriter Reputation, Initial Return and Long-Run Performance of IPO stocks", The Journal of Finance, 1998, 53(1):283-311.

[21].P.J. Lee, S.L. Taylor, and T.S. Walter, “Australian IPO pricing in the short and long run”, Journal of Banking and Finance, 1996, 20:1189-1210.

[22].G. Giudici and P. Roosenboom, “The long-term performance of Initial Public Offerings on Europe's new stock markets", Advances in Financial Economics, 2004, 10:329 - 354.

[23].K. Chan, J. Wang, and K.C.J. Wei "Underpricing and long term performance of IPOs in China”, Journal of Corporate Finance, 2004, 10(3):409-430.

[24].J. Cai and K.C. Wei, "The investment and operating performance of Japanese initial public offerings", Pacific Basin Financial Journal, 5:389-417, 1997. 
[25].M. Kooli and J. Suret, "The aftermarket performance of initial public offerings in Canada", Journal of Financial Management, 14:47-66, 2004.

[26]. N. Abu Bakar and S. Rosbi, "Long Term Performance of Islamic Share Price for Initial Public Offerings (IPOs) in Malaysia: Evidence from Sharia-Compliant Companies Listed on the Malaysian Stock Exchange (2006-2010)", International Journal of Management Science and Business Administration, 2016, 2(6):55-66.

[27]. M. Levis, “The Long-run performance of Initial Public offerings; The U.K. experience 1980-1988”, Journal Financial Management, 1993, 22:28-41.

[28].W. Bessler and S. Thies, "The long-run performance of initial public offerings in Germany", Managerial Finance, 2007, 33(6):420-441.

[29].J. How, R. Jelic, B. Saadouni, P. Verhoeven, P, "Share allocations and performance of KLSE second board IPOs", Pacific-Basin Finance Journal, 2007, 15(3):292-314. 